ISSN1027-5495. Functional Materials, 24, No.3 (2017), p. 496-500

doi:https://doi.org/10.15407/fm24.03.496

(C) 2017 - STC “Institute for Single Crystals"

\title{
Sensitivity analysis and proportioning design of rock burst similar materials
}

\author{
Yongsheng Liu ${ }^{1}$, Jin $\mathrm{Li}^{1}$, Qiulan W ${ }^{1}$, Wang $\mathrm{Liu}^{2}$ \\ ${ }^{1}$ School of Civil Engineering and Architecture, East China Jiaotong \\ University, Nanchang 330013, China \\ ${ }^{2}$ Nanchang Municipal Public Investment Group Co., Ltd.Nanchang \\ 330029 , China
}

Received January 25, 2017

\begin{abstract}
The rock burst similar material were prepared by quadratic orthogonal design. Sand ratio (A), cement plaster ratio (B), watered rate $(\mathrm{C})$ are used as the level influence factors, and the uniaxial compressive strength $\sigma_{C}$, the ratio of compressive and tensile strength $\sigma_{c} / \sigma_{t}$ and the impact energy index $W_{e t}$ was used as assessment index. The sensitivity of the influence factors to the rock burst tendency of similar materials was studied by the range analysis method. The results showed that: sand ratio (A) is the main influence factors to the compressive strength of rock burst material; the ratio of water $(\mathrm{C})$ is the main influence factor to the compressive and tensile strength ratio; cement gypsum ratio (B) is the main influence factor to impact energy index.
\end{abstract}

Key words: rock burst; similar material; orthogonal design; sensitivity; proportioning test

Получен и исследован материал подобный горной породе. Исследовалось влияние соотношения концентраций песка, гипсового цемента и воды на прочность материала на сжатие и растяжение. Результаты показали, что количество песка является основным средством воздействия на прочность на сжатие материала, количество воды является основным фактором влияния на коэффициент сжатия и растяжения, количество гипсового цемента определяет ударную прочность материала. Полученный материал может быть использован как модельный материал для изучения динамики взрыва горных пород.

Отримання і дослідження матеріалу подібного гірських порід. Yongsheng Liu, Jin Li, Qiulan Wu, Wang Liu

Одержано та досліджено матеріал подібний гірській породі. Досліджувався вплив співвідношення концентрацій піску, гіпсового цементу і води на міцність матеріалу на стиск і розтяг. Результати показали, що кількість піску е основним засобом впливу на міцність на стиск матеріалу, кількість води є основним фрактором впливу на коефіцієнт стиснення i розтягування, кількість гіпсового цементу визначає ударну міцність матеріалу. Отриманий матеріал може бути використаний як модельний матеріал для вивчення динаміки вибуху гірських порід.

\section{Introduction}

Rock burst is a phenomenon of rock burst and ejection under high earth pressure, it is due to underground excavation, changed the space environment of rock mass, and caused stress redistribution and stress concentration surrounding roadway. Rock burst will lead to a large area of rock collapse, caused supporting system failure, equipment buried, and even casualties, therefore, scholars have paid much attention to the research of rock burst in recent years. Field experimental research of rock burst affect the normal production of the project, is difficult to operate, and high cost and risk. 
Indoor similar model experiment is an important means for research rock burst, which has the advantage of good economic performance, strong controllability, scientific analysis of good effect and so on [1]. In recent decades, a large number of experts and scholars[2-4] at home and abroad have done lots of research on the problem of rock burst. Manchao He et al [5] experimental studied on the rock burst process of granite under high geological stress condition by using the deep rock burst process experiment system designed by themselves. The change rule of three principal stress and stress curves of the whole process of granite rock burst the stress curve of the whole process of the granite rock burst were obtained, and the rock burst intensity were classified according to the ratio of the maximum principal stress and uniaxial compressive strength. Yishan Pan[1] and Shuqing Yang [6] carried out the physical model experiment for study on the mechanism of rock burst. They used four kinds of different ratio of rock burst similar materials to establish similar model which length $\times$ width $\times$ thick is $80 \mathrm{~cm} \times 60 \mathrm{~cm} \times 20 \mathrm{~cm}$. Experimental results proved the existence of rock burst critical load, and the results are in agreement with the simulation and the theoretical results. Wentao Chen et al [7] carried out model experiment with rosin as model material under the condition of high hydrostatic pressure. The formulas for calculating strain energy and the velocity and kinetic energy of broken block were deduced based on the analysis of the characteristics of the velocity peak and the time characteristics of unloading wave based on the analysis of the velocity peak and unloading wave during dynamic crushing process.

The preparation of similar materials is the foundation for model experiment. Only if the material with strong rock burst is formulated, the model experiment of rock burst can be successful [8]. The strong rock burst tendency material were made up with sand, cement, gypsum and other raw materials, based on the research of concrete materials ratio, by sensitivity analysis and quadratic orthogonal design method [9].

\section{Determination conditions of rock burst}

In case of rock burst, the bearing material must have some specific conditions, for example: it should has better brittle characteristics and linear stress-strain relationship, and it has smaller strength ratio of compressive and tensile $\sigma_{c} / \sigma_{t}$ and larger impact energy index $W_{\text {et }}=W_{\mathrm{p}}^{c} / W_{\mathrm{t}}$, here $W_{\mathrm{p}}$ and $W_{\mathrm{t}}$ are the rise and fall section area of the stress-strain curve. When the characteristics of the material meet certain conditions, rock burst will occur. The relationship between rock burst intensity and material properties is shown in Table. 1.

\section{Orthogonal design test}

\subsection{Raw materials and specimen making}

The raw materials of rock burst similar materials are: Ganjiang River sand, its diameter $2 \mathrm{~mm}$; Portland cement with label 42.5R; gypsum; Borax solution with concentration of $1 \%$. The mould used for making specimen is the cylinder standard three open mould. In the process of manufacture, a thin layer of oil is evenly coated on the inner wall of the mould firstly, and then loading the already stirred material into the mould and vibrating to specimen forming. After formed, each specimen labeled, and then stripping after 48 hours at room temperature. The tests were carried out after 7 days of the natural state maintenance .

\subsection{Test scheme and results}

The tests adopt orthogonal design method. The ratio of cement gypsum (B) and the rate of water (C) were determined as influencing factor, and the uniaxial compressive strength, the ratio of uniaxial compressive strength and tensile strength and impact energy index were determined as evaluation index. The ratio of the level value of the three factors is shown as Table 2. According to the orthogonal table, 9 kinds of experiments were carried out, and each group was tested with 6 specimens. The compression strength and tensile strength of similar materials were obtained by the experi-

Table 1. Rock burst intensity and properties of material

\begin{tabular}{|c|c|c|c|c|}
\hline index Indesity & $\begin{array}{c}\text { Strong } \\
\text { rock burst }\end{array}$ & $\begin{array}{c}\text { Medium } \\
\text { rock burst }\end{array}$ & $\begin{array}{c}\text { Weak } \\
\text { rock burst }\end{array}$ & $\begin{array}{c}\text { No } \\
\text { rock burst }\end{array}$ \\
\hline $\begin{array}{c}\text { Ratio of compressive } \\
\text { and tensile }\end{array}$ & $\sigma_{\mathrm{c}} / \sigma_{t} \leq 10$ & $10<\sigma_{\mathrm{c}} / \sigma_{t} \leq 26.5$ & $26.7<\sigma_{\mathrm{c}} / \sigma_{t} \leq 40$ & $\sigma_{\mathrm{c}} / \sigma_{t}>40$ \\
\hline Impact energy & $W_{e t} \geq 3$ & $1.5 \leq W_{e t}<3$ & $W_{e t}<1.5$ \\
\hline
\end{tabular}


Yongsheng Liu et al. / Sensitivity analysis and proportioning ...

Table 2. Level value of influence factor

\begin{tabular}{|cccc|}
\hline Level value & The sand ratio(A) & The ratio of cement gypsum (B) & The rate of water (C) \\
\hline (1) & $62.5 \%$ & $3: 1$ & $11 \%$ \\
\hline (2) & $70 \%$ & $2: 1$ & $15 \%$ \\
\hline (3) & $75 \%$ & $1.5: 1$ & $19 \%$ \\
\hline
\end{tabular}

ments, and the impact energy index were calculated shown in Table 3.

According to Table 1 and Table 3, we can found that all the specimens are not strong rock burst material. The compressive strength and impact energy index and ratio of compression and tensile strength of the first group material are $3.92 \mathrm{Mpa}, 2.04$ and 11.43 . it is medium rock burst tendency material. So in order to prepare the strong rock burst material, we adjusted the ratio of materials properly based on the first group material.

\section{Sensitivity analysis}

\subsection{Range analysis method}

The range analysis method is to analyze the problem by calculating the average range of each factor. This method can get the relative size of each level factor to influence the test index, so as to find the main factors among all factors. Range analysis method using the formula (1) to calculate the range value D.

$$
\begin{aligned}
& D_{j}= \\
& \max \left\{\frac{I_{j}}{K_{j}}, \frac{I I_{j}}{K_{j}}, \frac{I I I_{\mathrm{j}}}{K_{\mathrm{j}}}\right\}-\min \left\{\frac{I_{j}}{K_{j}}, \frac{I I_{j}}{K_{j}}, \frac{I I I_{\mathrm{j}}}{K_{\mathrm{j}}}\right\}
\end{aligned}
$$

$I$ - the sum of numerical values of the test index corresponding to the " 1 " level of column $\mathrm{J}$; $I I_{j}$ - the sum of numerical values of the test index corresponding to the " 2 " level of column J; $I I I$ - the sum of numerical values of the test index corresponding to the " 3 " level of column J. $K_{j}$ - the number of times the same level appears in the $j$ column;

$D_{j}$ - range of column $\mathrm{j}$ equal to the maximum minus minimum which each level corresponds to the average value of the test parameters.

\subsection{Sensitivity analysis of influencing} factors

In order to analyze the influence factors of the three level factors on each evaluation index, the range analysis method were used to analyze each factor sensitivity in this paper. Based on the test results of the orthogonal test, each index influence factor were calculated by the formula (1), and the results are as shown in Table. 4.

The sensitivity of the assessment indicators about the various influencing factors are shown in Fig. 1. According to Fig. 1 (a) we know that the uniaxial compressive strength decreases with the sand ratio(A) increasing, decreases slightly with the ratio of cement gypsum(B) increasing, and has no obvious relationship with the ratio of water(C). The range of the above

\begin{tabular}{|c|c|c|c|c|c|c|}
\hline Serial number & $\mathrm{A}$ & $\mathrm{B}$ & $\mathrm{C}$ & $\sigma_{c}$ & $\sigma_{c} / \sigma_{t}$ & $W_{e t}$ \\
\hline 1 & (1) & (1) & (1) & 3.92 & 11.43 & 2.04 \\
\hline 2 & (1) & (2) & (2) & 4.43 & 12.28 & 2.47 \\
\hline 3 & (1) & (3) & (3) & 4.88 & 14.92 & 2.72 \\
\hline 4 & (2) & (1) & (2) & 3.13 & 12.32 & 1.87 \\
\hline 5 & (2) & (2) & (3) & 2.45 & 13.52 & 2.12 \\
\hline 6 & (2) & (3) & (1) & 2.96 & 9.56 & 2.02 \\
\hline 7 & (3) & (1) & (2) & 1.71 & 10.24 & 1.65 \\
\hline 8 & (3) & (2) & (3) & 2.21 & 12.71 & 2.15 \\
\hline 9 & (3) & (3) & (1) & 2.68 & 8.53 & 2.35 \\
\hline
\end{tabular}

Table 3. Results of orthogonal test 

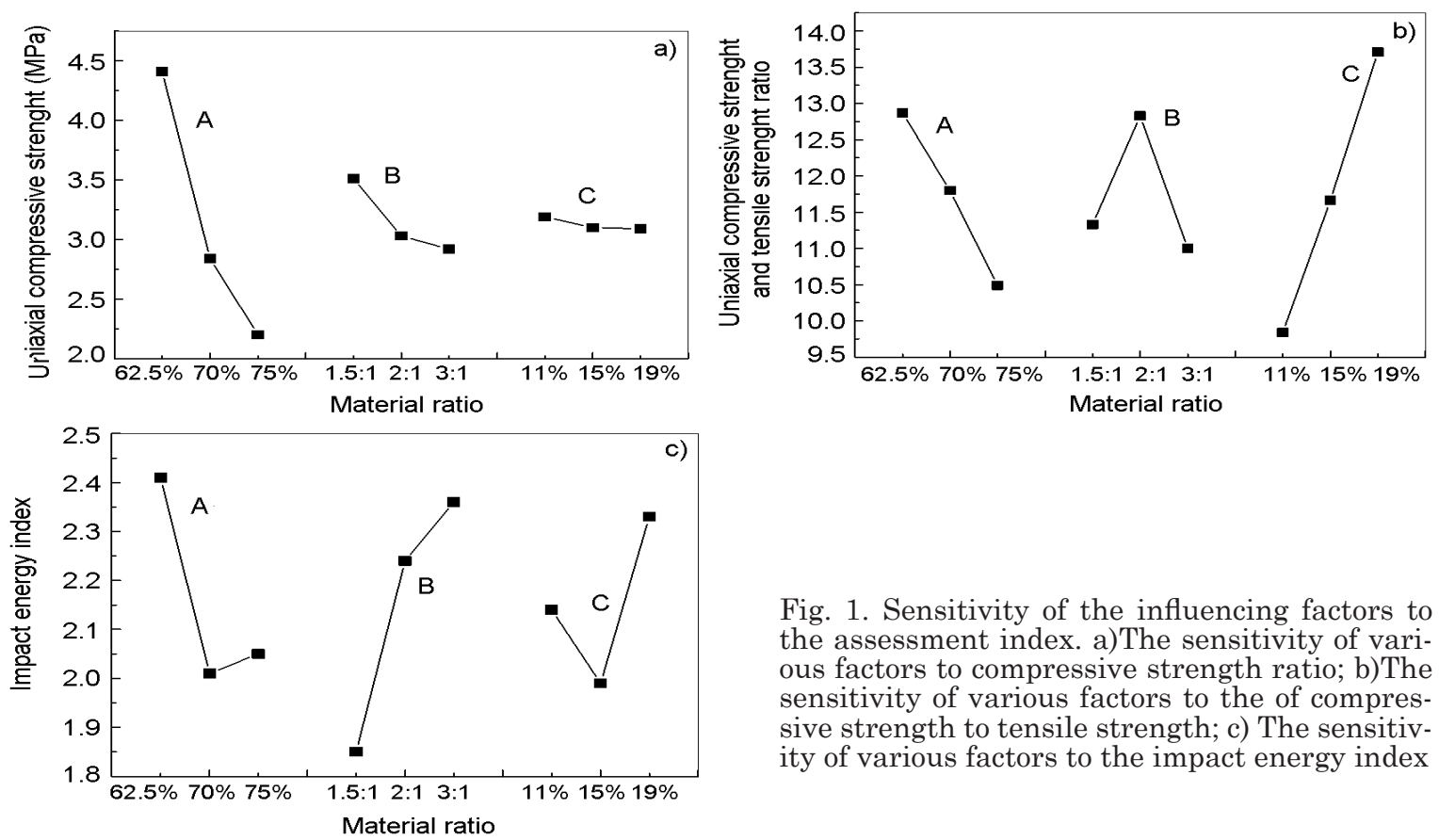

Fig. 1. Sensitivity of the influencing factors to the assessment index. a)The sensitivity of various factors to compressive strength ratio; $b$ )The sensitivity of various factors to the of compressive strength to tensile strength; c) The sensitivity of various factors to the impact energy index

Table 4. Results of sensitivity analysis

\begin{tabular}{|c|c|c|c|c|}
\hline \multirow{2}{*}{ Index } & & sand ratio (A) & $\begin{array}{c}\text { ratio of cement and } \\
\text { gypsum (B) }\end{array}$ & rate of water (C) \\
\hline \multirow{3}{*}{$\begin{array}{c}\text { Uniaxial compressive } \\
\text { strength }\end{array}$} & $\mathrm{k} 1$ & 4.41 & 2.92 & 3.19 \\
\cline { 2 - 5 } & $\mathrm{k} 2$ & 2.84 & 3.03 & 3.09 \\
\cline { 2 - 5 } & $\mathrm{k} 3$ & 2.20 & 3.51 & 3.08 \\
\hline \multirow{3}{*}{$\begin{array}{c}\text { Uniaxial compressive } \\
\text { strength and tensile } \\
\text { strength ratio }\end{array}$} & $\mathrm{range} \mathrm{D}$ & 2.21 & 0.59 & 9.11 \\
\cline { 2 - 5 } & $\mathrm{k} 1$ & 12.87 & 11.33 & 11.66 \\
\cline { 2 - 5 } & $\mathrm{k} 2$ & 11.80 & 12.83 & 13.71 \\
\hline \multirow{3}{*}{\begin{tabular}{c} 
Impact energy index \\
\cline { 2 - 5 }
\end{tabular}} & $\mathrm{k} 3$ & 10.49 & 11.00 & 3.87 \\
\cline { 2 - 5 } & $\mathrm{k} 2$ & 2.41 & 1.83 & 2.14 \\
\cline { 2 - 5 } & $\mathrm{k} 3$ & 2.01 & 1.85 & 2.33 \\
\hline
\end{tabular}

three factors are $2.21,0.59$ and 0.11 respectively. So the sensitivity intensity of each factor to the uniaxial compressive strength of specimens is $A, B, C$ in turn, and the sand ratio(A) is the main influence factor of the uniaxial compressive strength.

Similarly, the ratio of compressive and tensile strength increases with the ratio of water (C) increasing, decreases with sand ratio(A) increasing, have no obvious relationship with the ratio of cement gypsum(B). The range of the above three factor respectively is $3.87,1.83$ and 1.38. The sensitivity intensity of each factor to the ratio of compressive and tensile strength is $\mathrm{C}, \mathrm{B}, \mathrm{A}$ in turn, and the ratio of water $(\mathrm{C})$ is the main influence factor. The impact energy decreases with the ratio of cement gypsum (B) and the sand ratio(A) increasing, and has no obvious relationship with the ratio of water (C).
The range of the above three factors respectively is $0.51,0.36$ and 0.34 . The sensitivity intensity of each factor to impact energy is B,A,C in turn, and the ratio of cement gypsum(B) is the main influence factor for impact energy.

According to the sensitivity analysis of various factors, in order to matching the strong rock burst tendency similar material we should be reduce the ratio of cement gypsum and mixing water based on the first group material.

\section{Quadratic orthogonal design}

According to above analysis, quadratic orthogonal design were conducted and compressive and tensile experiment were carried out, then impact energy index of all specimens were calculated. The results were shown in Table 5 . 
Yongsheng Liu et al. / Sensitivity analysis and proportioning ...

Table 5. Experimental results of quadratic orthogonal designs

\begin{tabular}{|c|c|c|c|c|c|c|}
\hline \multirow{2}{*}{$\begin{array}{c}\text { Test serial } \\
\text { number }\end{array}$} & sand ratio & $\begin{array}{c}\text { Factors } \\
\text { ratio of ce- } \\
\text { ment and } \\
\text { gypsum }\end{array}$ & $\begin{array}{c}\text { Rate of } \\
\text { water, } \%\end{array}$ & $\begin{array}{c}\text { Rock burst tendency to judge index } \\
\text { compressive } \\
\text { strength, } \\
\text { MPa }\end{array}$ & $\begin{array}{c}\text { The ratio } \\
\text { of compres- } \\
\text { sive strength } \\
\text { and tensile } \\
\text { strength }\end{array}$ & $\begin{array}{c}\text { impact en- } \\
\text { ergy index }\end{array}$ \\
\hline 1 & $62.5 \%$ & $2.5: 1$ & 9 & 4.01 & 10.67 & 2.67 \\
\hline 2 & $62.5 \%$ & $2: 1$ & 8 & 4.11 & 9.52 & 3.02 \\
\hline 3 & $62.5 \%$ & $1.5: 1$ & 7 & 4.26 & 9.12 & 3.11 \\
\hline 4 & $65 \%$ & $2.5: 1$ & 8 & 3.83 & 10.05 & 2.55 \\
\hline 5 & $65 \%$ & $2: 1$ & 7 & 3.91 & 9.72 & 2.72 \\
\hline 6 & $65 \%$ & $1.5: 1$ & 9 & 4.05 & 10.27 & 2.87 \\
\hline 7 & $67.5 \%$ & $2.5: 1$ & 8 & 3.52 & 9.83 & 2.33 \\
\hline 8 & $67.5 \%$ & $2: 1$ & 9 & 3.63 & 10.25 & 2.45 \\
\hline 9 & $67.5 \%$ & $1.5: 1$ & 7 & 3.78 & 9.55 & 2.71 \\
\hline
\end{tabular}

Form the Table 5, the uniaxial compressive strength of the third group specimen is 4.26 $\mathrm{MPa}$, and its compressive tensile ratio is 9.12 , impact energy index is 3.11. Comprehensive analysis of indicators, we know that third group material is strong rock burst materials, and the third piece in Table $\mathbf{5}$ is the optimal proportion of the strong rock burst tendency.

\section{Conclusions}

According to the test results and sensitivity analysis, the following conclusions are obtained:

(1) The sensitivity analysis of three levels of influencing factors on evaluation indicators were conducted by range analytical method. The results showed that the sand ratio (A) is the main influence factors of the uniaxial compressive strength; the rate of water $(\mathrm{C})$ is the main influencing factors for the rate of compressive tensile strength; the ratio of cement and gypsum (B) is the main influencing factors for the impact energy index.

(2) According to the second orthogonal design, the optimum proportion of the strong rock burst material is obtained. The proportion is as follows: the mixed sand rate is $62.5 \%$, the rate of cement and gypsum is $1.5: 1$ and the ratio of water is $7 \%$.

(3) Research shows that quadratic orthogonal design method and sensitivity analysis can make a strong rock similar material. This method is scientific and reasonable, and can reduce test times and consumption to a certain extent, optimize scheme, so the method has good applicability.

\section{Acknowledgements}

This work is supported by the Chinese Natural Science Foundation (51664014, 51274101) and Science and technology project of Jiangxi Provincial Department of Education (GJJ160474).

\section{References}

1. Pan Yi Shan, Zhang Mengtao, Wang Laigui et al. J. Geotechn. Eng., 4, 49, 1997

2. Qian Qi Hu., Rock Soil Mech., 35 (1), 1, 2014.

3. Y.R. Stagey, Proceedings of the First International Conference on Rock Dynamics and Applications. Lausanne, CRC Press, 57, 2013.

4. Chen Zongii, Chinese J. Rock Mech. Eng., 6 (1),1, 1987.

5. Manchao He, Miao Jinli, Li Dejian et al. CChinese J. Rock Mech. Eng., 26 (5), 865, 2007.

6. Yang Shuqing, Eng. J. Wuhan Univ., 6 (2), 160, 1993.

7. Chen Wentao, Song Chunming, Cheng Tingting et al. Exp. Mech., 27 (5), 630, 2012,

8. Li Tianbin, Wang Xiangfeng, Meng Lubo, Chinese J. Rock Mech. Eng., S1,2610 2011.

9. Liu Ruijiang, Zhang Yewang, Wen Chongwei et al., Exp.Techn. Manag., 9, 52, 2010. 